\title{
Impacts of Teacher-Written Corrective Feedback with Teacher-Student Conference on Students' Revision
}

\section{Ida Isnawati}

Ph.D Student, Graduate School, English Language Education, Universitas Negeri Malang, East Java, Indonesia, ida.isnawati@ gmail.com

\section{Gunadi Harry Sulistyo}

Prof., Graduate School, English Language Education, Universitas Negeri Malang, East Java, Indonesia, gunadi.hs@gmail.com

\section{Utami Widiati}

Prof., Graduate School, English Language Education, Universitas Negeri Malang, East Java, Indonesia, utami.widiati.fs@um.ac.id

\section{Nunung Suryati}

Asst. Prof., Graduate School, English Language Education, Universitas Negeri Malang, East Java, Indonesia, nunung_suryati@yahoo.com

Although providing students with teacher written corrective feedback for their writing is considered critical, research has not come to conclusive findings on which form of written corrective feedback can best promote students' learning. Students still face a lot of problems in making sense of written corrective feedback from their teachers. Hence, interaction between teacher and student is necessary to solve such problem of feedback communication. Responding to this issue, the present study was intended to examine the effects of teacher written corrective feedback combined with teacher-student conference on students' revision in writing a cause-effect essay. Two intact classes of 73 students taking an academic writing course at Institut Agama Islam Negeri - IAIN - Tulungagung were involved in this study. A cause-effect writing prompt and a revision scoring rubric were developed for use as the instruments to collect data on students' making revisions. The findings show that there is no statistical significant difference in the mean scores of the revisions of the students given teacher written corrective feedback combined with teacher student conference and those of students provided with teacher written corrective feedback only.

Keywords: teacher corrective feedback, teacher-student conference, writing revision, teachers, learning

Citation: Isnawati, I., Sulistyo, G. H., Widiati, U., \& Suryati, N. (2019). Impacts of Teacher-Written Corrective Feedback with Teacher-Student Conference on Students' Revision. International Journal of Instruction, 12(1), 669-684. https://doi.org/10.29333/iji.2019.12143a 


\section{INTRODUCTION}

Feedback is believed to have a central role in students' learning and achievement (Carles, Salter, Yang \& Lam, 2011; Ellery, 2008; Ellis, Sheen, Murakami \& Takashima, 2008; Higgins, Hartley, \& Skelton, 2002; Nakata, 2015; Nicol \& Macfarlane-Dick, 2006; Sendziuk, 2010; Shute, 2008). This is due to various functions of feedback for example as a medium for informing the students about their performance in order to reach the learning goals as well as for motivating and reinforcing their learning behavior (Nelson \& Schunn, 2009). Therefore, providing students with feedback in its various forms such as teacher feedback (e.g. Ferris, 2014; Mahfoodh, 2016; Montgomery \& Baker, 2007), peer and collaborative feedback (e.g. Wang, 2014; Chong, 2016), the provision of oral feedback in writing conferences (e.g. Bitchener, Young \& Cameron, 2005), and computer-mediated feedback (e.g. Arslan, 2014) have been recommended and practiced in the classroom so far.

In a writing class in particular, the most frequently used form of feedback is teacher written corrective feedback as shown in a great number of studies on it such as those conducted by Ellis, Sheen, Murakami \& Takashima (2008), Frear \& Chiu (2015), Hosseiny (2014), Van Beuningen, Jong \& Kuiken (2008), and many others. Such feedback is also shown to significantly contribute to students' writing development (Bitchener, 2008; Chandler, 2003; Ellis et al., 2008) in which one of its advantages is improving the students' accuracy in writing.

Despite the potential use of teacher's feedback in writing class, students faced some challenges especially in making sense of their teacher's written feedback as revealed by Beaumont, O’Doherty, \& Shannon (2011), Bloxham \& Campbell (2010), and Burke (2009), and McCarty (2015). For example, as found by Beaumont et al., (2011), communication failure happened because of different perceptions between teachers and students where students expected more detailed guidance while teachers assumed that students had the ability for independent learning. Another problem of understanding teacher's feedback is also reported to be in the form of students' limited understanding of their teachers' expectation and standard of performance (Bloxham \& Campbell, 2010). In addition, upper-intermediate and advanced students' unsatisfied response to their teachers' feedback practice identified in Nemati, Alavi, Mohebbi, \& Masjedlou's (2017) study could also be an indication that students had some problems in responding their teachers' feedback.

All the above mentioned students' problems with their teacher feedback provision clearly indicate that simply providing students with feedback alone is not sufficient (Crisp, 2007). For feedback to be impactful, there must be other ways to build a closer interaction between the teacher and students in communicating the feedback because teachers' feedback which is not understood and responded appropriately by students will be ineffectual on students' learning progress.

\section{LITERATURE REVIEW}

\section{Teacher Written Corrective Feedback}

As one form of teacher feedback, written corrective feedback remains the most controversial yet interesting issue among the researchers of feedback in writing, 
particularly after Truscott's (1996) work proposing the negative effects of grammar correction. His suggestion to abandon grammar correction is mainly because of time inefficiency for both students and teachers. Students who take correction seriously will have to spend much time reading, thinking about, and correcting their mistakes while actually it is much better for them to spend their time for other more productive learning activities. In the same way, teachers, especially in class with many students, need an enormous amount of their time for grammar error correction and practically, they cannot provide adequate and consistent feedback. Moreover, although teachers provide written corrective feedback, it does not guarantee that students are able or willing to use such feedback effectively in their learning process. Furthermore, he adds that in cases where teachers provide corrective feedback on students' grammatical errors, there is the possibility that students might avoid using such forms so that they come to use only simply-structured sentences instead of more complex one.

As the reactions to Truscott's (1996) work, a lot of research highlighted the effectiveness of giving written corrective feedback for students' writing improvement (e.g. Bitchener, 2008; Chandler, 2003; Ellis et al., 2008). In his study, Bitchener (2008), for example, investigated the efficacy of written corrective feedback by assigning four groups of students with direct corrective feedback combined with written and oral metalinguistic explanation, direct corrective feedback and metalinguistic explanation, direct feedback only, and no corrective feedback for control group. The study found that the accuracy of students who received written corrective feedback in the immediate and delayed post-test outperformed those in the control group who did not receive corrective feedback. Besides, Chandler's (2003) study also indicates that students in experimental group who did error correction made significant improvement in accuracy within 10 weeks compared to control group who did not do error correction.

Despite the on-going controversy on the effectiveness of written corrective feedback, the above findings clearly refute the claim that having error correction is ineffective. On the other words, it is to say that the corrective feedback provision, particularly written corrective feedback, brings positive impacts toward students' writing.

\section{Teacher Written Corrective Feedback with Teacher-Student Conference}

As indicated in some studies by Beaumont et.al. (2011), Bloxham \& Campbell (2010), Burke (2009), and McCarty (2015) in which students frequently faced problems in understanding their teacher's feedback, a socio-constructivism learning paradigm seems to be the appropriate solution for effective communication and closer interaction between the teacher and students. Such a paradigm suggests that feedback provision should not only play a role for information transfer to students as a passive recipient of feedback but also open an opportunity for more dialogs with students with their active role (Ajjawi \& Boud, 2015; Hyland, 2010). In order to implement such a learning paradigm, providing written corrective feedback combined with a teacher-student conference where the teacher and students have one-on-one conversations on student's writing (Bayraktar, 2012) can be an alternative strategy of having dialogical feedback provision of which effectiveness is worth investigating. 
Several studies have revealed the advantages of having a teacher-student conference in writing classes. One study by Crimmins, Nash, Oprescu, Liebergreen, Bond \& Dayto (2014) pointed out that by having a teacher-student conference, students can talk freely, get assistance from the teacher, be more engaged in learning, and develop in themselves their self-regulated learning. Another study by Yeh (2016) asserted that a teacherstudent conference can best give the students opportunities to have individualized and personalized instruction. Further, during the conference, it is also possible for the teacher to understand and clarify students' individual needs and problems in a better way. In the same way, students, especially shy students, may also get an opportunity to ask questions or express their opinions personally without any hesitation. A more recent study conducted by Hamlaoui and Fellahi (2017) found the effectiveness of having teacher-student conferencing in writing class on students' grammatical accuracy.

Considering the advantages of having teacher written corrective feedback and a teacherstudent conference in a writing class mentioned previously, having teacher written corrective feedback combined with teacher-student conference certainly is argued to bring together all advantages of those two worthy practices. With such a strategy, more importantly, the problems of feedback communication between the teacher and students are likely to be solved simultaneously.

Despite the potential benefits described previously, the feedback provision strategy by combining teacher written corrective feedback with teacher-student conference in a writing class has not been elaborately investigated so far. Crimmins et al.'s (2014) research was one study trying to investigate the students' perception toward a combination of written and dialogic feedback called as the Written, Reflective and Dialogic Feedback (WRDF) strategy. The results show that the teacher and students were very satisfied with the strategy; students were more engaged in learning, and developed their help-seeking behavior and self-regulated learning.

Such research on the effectiveness of combination of written and dialogic feedback provision is indeed valuable. However, research on it has been scarcely conducted so far and therefore, more studies are needed to elucidate more conclusive effects of a similar strategy on particularly students' cause-effect writing.

The current study was intended to investigate the effects of having teacher written corrective feedback combined with teacher-student conference on students' revision of cause-effect writing. In order to make the current study more focused, two research questions are formulated as follows:

1. Do the students provided with teacher written corrective feedback combined with teacher-student conference and those provided with only teacher written corrective feedback have a significant difference in their mean scores of their revised writing?

2. Do the students provided with teacher written corrective feedback combined with teacher-student conference and those provided with only teacher written corrective feedback have a significant difference in their mean scores of the writing components of revisions? 


\section{METHOD}

This study was a quasi-experimental in design and was a part of a larger study in the field of teacher written corrective feedback. As the preliminary study, the results of this study was, therefore, very prominent in deciding the direction of the future larger studies.

\section{Participants}

This study involved 73 university students in two intact classes which were randomly assigned to the experimental and the control groups. 34 students were in the experimental group while 39 were in the control group. These two groups in this study were the third semester students taking the Academic Writing Course at the English Department of IAIN Tulungagung, Indonesia. Through Levene's Test of the SPSS 20 version, the two classes were found to have equal English proficiency as their scores of Test of English as a Foreign Language (TOEFL) statistically showed insignificant difference $(\mathrm{p}=0.42>$ sig. $=0.05)$. The TOEFL scores were properly used to check the two groups' equality in this study for the assumption that students having equal English proficiency, their English skills, including their writing skill, were considered to be equal as well. Thus, having this evidence, the two groups were equally comparable for further testing the effect of providing teacher written corrective feedback combined with teacher-student conference on students' success in revision.

\section{Instruments}

The instruments employed in this study were a cause-and-effect writing prompt and a writing scoring rubric. In the writing prompt, the students were required to follow a set of activities in writing a five-paragraph cause-and-effect essay, starting from outlining, drafting, writing, and revising. Three topics of effects of using social media, effects of consuming drugs, and causes of traffic accidents were provided to be chosen by the students for their cause-effect essay. For the detailed writing prompt, see Appendix A.

Beside the writing prompt, the scoring rubric was developed to determine the students' revision quality. It dealt with two components of writing i.e. essay structure and its language use. The essay structure included some indicators on the content and the organization of the essay while the language use has something to do with several essential indicators on the use of grammar, the mechanics, the punctuation, the spelling, and the word choice in the essay. For each component, there were four levels of scores in a range from 1 to 4 representing "poor", "fair", "good", and "very good" respectively. The weight for the two components was the same. See Appendix B for the writing scoring rubric.

Both the writing prompt and the scoring rubric had been through expert validation process and the results showed that the writing prompt had appropriate topics for the cause-effect writing as well as clear instructions for students' writing. For the scoring rubric, the reliability checks of the results of the raters' rating the students' writing scores involving the Pearson Product Moment Correlation and Intra Class Correlation Coefficient (ICC) of the SPSS showed a high reliability coefficient of .812. Thus, these instruments were considered to be reliable for the purpose of data collection in the present study. 


\section{Treatment Procedures}

In this study, the treatment was conducted in four weeks with four meetings held inside the class and some activities outside the class. Both the experimental and the control groups were taught by the same lecturer in their writing class. The procedures of treatment consisted of the introduction of cause-and-effect organization and the use of some codes for written corrective feedback, the outline writing stage, the drafting stage, the writing stage, and the written-corrective feedback provision. The procedures for both classes were all the same. The only difference in the treatment for both classes was the administration of teacher-student conference for the experimental class which was conducted outside the writing class during the third week of treatment. When the control group was required to revise their writing based on the coded written corrective feedback provided by the lecturer, the experimental group was given an opportunity to meet the lecturer outside the classroom to have a five-minute teacher-student conference before they revised their essays.

The detailed procedures of treatment for the experimental class by combining teacher written corrective feedback and teacher-student conference in this study were as follows. In the first meeting, after the students were introduced to the cause-effect essay and the codes for written corrective feedback, they were required to make an essay outline and develop it into a five-paragraph essay in the classroom in the second week. The students' essays were then submitted to have teacher written corrective feedback. The written corrective feedback was in the form of coded feedback in which the codes had been discussed and agreed between the lecturer and the students (See Appendix C for the feedback codes). In the third week, the students were required to meet the lecturer one by one in the lecturer office to take their essay, check the written corrective feedback given in their writing draft for some time and have the conference with the lecturer for about 5 minutes for each student. The teacher-student conference was held in Indonesian language in order to create a closer interaction and smooth communication between the lecturer and the student since English is considered as a foreign language in Indonesia. During the conference, the lecturer asked the student whether s/he could identify his/her mistakes from the feedback given by the lecturer. Then, the lecturer offered whether the student had questions about the written corrective feedback and if any, answered the student's questions without telling him/her the correct forms. Throughout the conference, the lecturer led the students to be aware of their mistakes without telling them the correct forms when they have problems in identifying the mistakes.

Before the conference was ended, the lecturer suggested the students to consult their textbooks on grammar or essay writing after the conference when the student still didn't know the mistakes and how to correct them. Finally, the revised essays were submitted in the fourth week of treatment.

\section{Data Analysis}

Prior to the analysis, the process of scoring the students' revisions was conducted. Two writing components of the scoring rubric, i.e., essay structure and language were used as 
the reference in scoring the students' revisions. The scores were calculated by adding the score for each writing component, then dividing it with eight as the maximum score, and finally multiplying it with 100 . Thus, the highest score of the student essay was 100 and the lowest was 25 .

After all data were obtained in the form of scores of students' revisions, the data went through the descriptive statistics analysis as well as homogeneity and normality testing before the main statistical analysis was conducted. The main inferential statistical analysis was then conducted by using SPSS 20 to answer the research questions of this study.

\section{FINDINGS}

The first findings of the current study are related with the first research question on whether there is any significant difference in the mean scores of the revisions of the students provided with teacher written corrective feedback combined with teacherstudent conference and those who were not. Preceding the main inferential statistical analysis, it is necessary to describe the data. The results of descriptive statistics are shown in Table 1.

Table 1

Descriptive Data of Students' Scores of Revision

\begin{tabular}{lcccccc}
\hline & $\mathrm{N}$ & Range & Minimum & Maximum & Mean & Std. Deviation \\
\hline Experimental & 34 & 50.00 & 50.00 & 100.00 & 75.18 & 13.00 \\
Control & 39 & 50.00 & 50.00 & 100.00 & 70.39 & 13.65 \\
\hline
\end{tabular}

Table 1 visually shows that the mean score of the experimental group was greater than that of the control group in which the mean score of the experimental group was 75.18 and the mean score of the control group was 70.39. The range score of the experimental group was 50, from the minimum score of 50 to the maximum score of 100 , while the standard deviation was 13.00 . The range score of the control group was 50, ranging from the minimum score of 50 to the maximum score of 100 . The standard deviation of the control group was 13.65. From the mean scores, it is clear that the experimental group had a greater mean score than that of the control group. The standard deviation scores also indicate that the scores of the students in the control group had a greater variation around the mean compared to those of the experimental group although the highest score and the lower scores of both groups were exactly the same.

In addition, prior to the main data analyses, it is also essential to fulfill the statistical assumptions involving homogeneity and normality testing (Peers, 2006:294). In order to examine the homogeneity of the data between the revision scores of the students in the experimental and control groups, the Levene's test was conducted by using SPSS 20 version. The result showed that both classes were considered homogeneous $(p=0.266>$ sig. $=0$.05). See Table 2

Table 2

Test of Homogeneity of Variances

\begin{tabular}{llll}
\hline Levene Statistic & df1 & df2 & Sig. \\
\hline 1.257 & 1 & 71 & .266 \\
\hline
\end{tabular}


In addition to the homogeneity testing, the normality testing employing KolmogorovSmirnov test showed that the data on students' revisions in the experimental group was not normally distributed $(p=0.01<$ sig. $=0.014)$ while those of the control group was normal $(p=0.098<\operatorname{sig} .=0.05)$. See Table 3 .

Table 3

One-Sample Kolmogorov-Smirnov Test

\begin{tabular}{llll}
\hline & & Experimental & Control \\
\hline $\mathrm{N}$ & & 34 & 39 \\
Normal Parameters & Mean & 75.18 & 70.35 \\
& Std. Deviation & 13.00 & 13.65 \\
& Absolute & .270 & .196 \\
Most Extreme Differences & Positive & .270 & .188 \\
& Negative & -.200 & -.196 \\
Kolmogorov-Smirnov Z & & 1.575 & 1.23 \\
Asymp. Sig. (2-tailed) & & .014 & .098 \\
\hline
\end{tabular}

As the results of homogeneity and normality testing which mostly fulfilled the statistical assumptions, an independent sample t-test was used for further analysis to investigate whether there is any significant difference in the mean scores of the revisions of the students who were provided with teacher written corrective feedback combined with teacher-student conference and those who were provided with teacher corrective feedback only.

The first analysis was related with the significant difference in the mean scores of the experimental and the control groups. The results of comparing the two mean scores can be seen in Table 4. The analysis using the independent sample t-test showed no significant difference in the mean scores of the revisions of the students who were provided with teacher written corrective feedback combined with teacher-student conference and those who were provided with only teacher written corrective feedback because the significant value was greater than the alpha at the significance level of 0.05 $(p=0.131>$ sig. $=0.05)$.

Table 4

Independent Samples t-Test

\begin{tabular}{|c|c|c|c|c|c|c|c|}
\hline & \multicolumn{7}{|c|}{ t-test for Equality of Means } \\
\hline & \multirow[t]{2}{*}{$\mathrm{T}$} & \multirow[t]{2}{*}{$\mathrm{df}$} & \multirow{2}{*}{$\begin{array}{l}\text { Sig. } \\
(2- \\
\text { tailed) }\end{array}$} & \multirow[t]{2}{*}{$\begin{array}{l}\text { Mean } \\
\text { Difference }\end{array}$} & \multirow[t]{2}{*}{$\begin{array}{l}\text { Std. Error } \\
\text { Difference }\end{array}$} & \multicolumn{2}{|c|}{$\begin{array}{l}\text { 95\% Confidence Interval } \\
\text { of the Difference }\end{array}$} \\
\hline & & & & & & Lower & Upper \\
\hline $\begin{array}{l}\text { Equal variances } \\
\text { assumed }\end{array}$ & 1.530 & 71 & .131 & 4.792 & 3.133 & -1.454 & 11.038 \\
\hline $\begin{array}{l}\text { Equal variances } \\
\text { not assumed }\end{array}$ & 1.535 & $\begin{array}{l}70 . \\
423\end{array}$ & .129 & 4.792 & 3.122 & -1.434 & 11.018 \\
\hline
\end{tabular}

Although there was no significant difference in the mean scores between the students of the experimental group with those of the control group in terms of their overall revised writing, it was necessary to find out whether there is any significant difference in the components of students' revised writing dealing with the essay structure and the 
language use. It was the answer for the second research question. A statistical computation by using one-way ANOVA was employed to find such a difference. The students' mean scores of revised writing in terms of essay structure and language use components is presented first in Table 5 before the one-way ANOVA results are shown in Table 6.

Table 5

Mean Scores of Writing Components of the Experimental and the Control Groups

\begin{tabular}{lll}
\hline & \multicolumn{2}{c}{ Writing Components } \\
& Essay Structure & Language Use \\
\hline Experimental & 37.13 & 37.87 \\
Control & 36.22 & 33.97 \\
\hline
\end{tabular}

From Table 5, it can be seen that the mean scores of the two writing components of the experimental group were higher than those of the control groups. For the component of essay structure, the experimental group got the mean score of 37.13 while the control group got the mean score of 36.22. In terms of the language use component, the experimental group also achieved the higher mean score of 37.87 than the control group who got 33.97 .

Next, to find out the significant difference in the components of students' revised writing dealing with the essay structure and the language use, statistical calculation using one way ANOVA was conducted. The results showed that the $p$ value for the essay structure was 0.612 while the $p$ value for the language use was 0.034 . This showed that the significant value for the essay structure was higher than the alpha at 0.05 significance level and, thus, there was no significant difference in the mean scores of the essay structure $(\mathrm{p}=0.612>$ sig. $=0.05)$. On the other hand, the analysis revealed that a significant difference was found in the mean scores of the language use since the $p$ value for the language use was less than the alpha at 0.05 significance level $(p=0.034<$ sig. $=$ $0.05)$. See Table 5.

Table 5

Results of One Way ANOVA on Students' Writing Components

\begin{tabular}{lllllll}
\hline \multirow{2}{*}{$\begin{array}{l}\text { Essay } \\
\text { structure }\end{array}$} & Sum of Squares & Df & Mean Square & F & Sig. \\
\cline { 2 - 7 } & Wetween Groups & 15.188 & 1 & 15.188 & .260 & .612 \\
\cline { 2 - 7 } & Tothin Groups & 4150.052 & 71 & 58.451 & & \\
\hline \multirow{2}{*}{$\begin{array}{l}\text { Language } \\
\text { use }\end{array}$} & Between Groups & 4165.240 & 72 & & & \\
\cline { 2 - 7 } & Within Groups & 4198.129 & 71 & 59.129 & & \\
\cline { 2 - 7 } & Total & 4473.459 & 72 & & & \\
\hline
\end{tabular}

From the findings of the statistical analysis above, it can be noted that although the difference in the mean scores of the students' overall revised writing was not statistically significant, the mean scores of one of the components of students' revised writing, i.e., the language use, was empirically found to be different significantly. Furthermore, since the mean score of the language use of the students in the experimental group was greater than that of the students in the control group, the students of the experimental group outperformed those of the control group in revising their writing especially in terms of 
the language use. In short, it was to say that the provision of teacher written corrective feedback combined with teacher-student conference experimented in this study facilitated students' language use in revising their writing cause-effect essays.

\section{DISCUSSION}

The result of the statistical analysis in the present study revealed that there was no significant difference in the mean scores between the students in the experimental group and the control group. It means that the students who were provided with teacher written corrective feedback combined with teacher-student conference did not produce a better revision in writing cause-and-effect essays compared to those given teacher written corrective feedback without a teacher-student conference. Although this finding seems not to be in line with the students' satisfaction of having written and dialogic feedback (Crimmin et. al, 2014), the result of descriptive statistics on the mean scores of both groups showed that the students provided with teacher written corrective feedback combined with teacher-student conference got a mean score greater than those given written corrective feedback without teacher-student conference. This implies a possibility of positive tendency of students' having better revision in writing if teacher written corrective feedback combined with teacher-student conference is implemented in a longer period of time. As it was explained before, in the present study, the provision of teacher written corrective feedback combined with teacher-student conference was only employed once in the writing class. A repeated use of the strategy in future studies may result in different findings.

With reference to the components of writing, in which two components of essay structure and language use were concerned in this study, the results showed that there was a significant difference in the mean scores of the language use in the students' revised writing. Regarding the statistical difference in the mean scores of both groups, the students provided with teacher written corrective feedback combined with teacher student conference were found to use better language in their revised writing compared to the students provided with teacher written corrective feedback only. This is partly in line with Bitchener's (2008) and Chandler's (2003) results of studies on the effectiveness of providing written corrective feedback in improving students' language accuracy in writing. Although the focus of the previous studies was on written corrective feedback only, and not on teacher-student conference, the greater mean score of the students' components of writing clearly indicates that the combination of teacher written corrective feedback and teacher-student conference was potentially used to improve students' writing.

The finding on the effect of providing teacher written corrective feedback with teacherstudent conference on the students' language use in which the students given teacher written corrective feedback combined with teacher-student conference outperformed those given teacher written corrective feedback may due to the students' greater attention in responding the feedback and revising their writing. As it was noticed during the treatment, students who were provided with teacher written corrective feedback combined with teacher-student conference seemed to be more engaged in responding to the teacher's written feedback and some of them enthusiastically asked more questions 
related with the feedback they got. The non-threatening atmosphere during the conference through the student's personal dialogs with the lecturer was believed to be the explanation for students' greater engagement. Such an increased engagement in learning and students' help-seeking behaviors were also noted in Crimmin et al.'s (2014) study and were thought to make students more enthusiastically work harder in revising their writing. This way, the combination of teacher written corrective feedback with teacher-student conference promotes an affective learning context that contributes to success in improving students' language use in writing cause-and-effect essays.

Beside the students' greater engagement in responding the written corrective feedback, another fact that might lead to the significant difference in the students' language use in both groups was the quantity of the provision of the teacher written corrective feedback in terms of language use which was greater compared to that of the organization and the content of writing. From the treatment, it can be noted that in one piece of student's writing, the lecturer generally gave around $90 \%$ of the written corrective feedback dealing with word choice, grammar, punctuation and mechanics. Only $10 \%$ of the feedback was on the content and the organization of the essay. Moreover, some of students' drafts were not provided with any feedback dealing with content and organization of the essay. Such lecturer's tendency in giving more written corrective feedback on students' language is actually commonplace because it actually goes with the nature of corrective feedback itself as a methodology to bring students' more attention to language form in the context of task performance (Ellis, 2005; Van Beuningen, 2010) than meaning. Based on this fact, it really makes sense when the students responded to lecturer's feedback and they thus become more aware on language use in writing than on other aspects such as the organization and the content of writing.

Despite the abovementioned context, the combination of teacher written corrective feedback and teacher-student conference in the present study was only conducted once and this is the limitation of the present study which might bring less potent impacts of the strategy on students' revision. It is believed that repeated and intensive use of the strategy with more meeting sessions will bring more positive impacts on students' writing performance. Therefore, more intensive studies implementing the strategy within a longer period of time need to be conducted in the future.

\section{CONCLUSION}

The present preliminary study has provided some evidence on the potential use of written corrective feedback in general and the combination of teacher written corrective feedback with teacher-student conference in particular. Although a significant difference could not be clearly identified by comparing the mean scores of both groups in the present study, one writing aspect of language use was found to be affected by the implementation of the strategy. This brings a positive implication on using teacher written corrective feedback combined with teacher-student conference in writing classes. To be more specific, providing teacher written corrective feedback can facilitate students' revision especially in terms of students' language accuracy when it is accompanied with teacher-student conference. This is mainly because the students can 
make sense of the written feedback from the lecturer for their successful revision in writing.

As a final remark, since this study has a limitation in terms of its short treatment period, more studies with longer and more intensive use of written corrective feedback as well as teacher-student conference modes need to be conducted to get more valid results. In addition, in order to reveal the students' responses to teacher written corrective feedback and teacher written corrective feedback combined with teacher-student conference, some qualitative studies are urgently required to gain deeper understanding of feedback mechanism in students' learning process.

\section{REFERENCES}

Ajjawi, R. \& Boud, D. (2015). Researching feedback dialogue: an interactional analysis approach. Assessment \& Evaluation in Higher Education 42(2), 252-265. DOI: 10.1080/02602938.2015.1102863.

Arslan, R.S. (2014). Integrating feedback into prospective English language teachers' writing process via blogs and portfolio. The Turkish Online Journal of Educational Technology 13(1), 131-150.

Bayraktar, A. (2012). Teaching writing through teacher-student writing conferences. Procedia - Social and Behavioral Sciences 51, 709 - 713.

Bayraktar, A. (2013). Nature of interactions during teacher-student writing Conferences, Revisiting the potential effects of self-efficacy beliefs. Egitim Arastirmalari-Eurasian Journal of Educational Research, 50, 63-86.

Beaumont, C., O’Doherty, M., \& Shannon, L. (2011). Reconceptualising assessment feedback: a key to improving student learning? Studies in Higher Education, 36(6), 671687.

Bitchener, J. (2008). Evidence in support of written corrective feedback. Journal of Second Language Writing 17, 102-11.

Bitchener, J., Young, S., \& Cameron, D. (2005). The effect of different types of corrective feedback on ESL student writing. Journal of Second Language Writing 14, 191-205.

Bloxham, S., \& Campbell, L. (2010). Generating dialogue in assessment feedback: Exploring the use of interactive cover sheet. Assessment \& Evaluation in Higher Education, 35, 291-300. doi: 10.1080/02602931003650045.

Burke, D. (2009). Strategies for using feedback students bring to higher education. Assessment and Evaluation in Higher Education, 34, 41-50. doi:10.1080/02602930801895711.

Carless, D.; Salter, D.; Yang, M. \& Lam, J. (2011). Developing sustainable feedback practices. Studies In Higher Education, 36(4), 395-407. 
Chandler, J. (2003). The efficacy of various kinds of error feedback for improvement in the accuracy and fluency of L2 student writing. Journal of Second Language Writing 12, 267-296.

Chong, I. (2016). How students' ability levels influence the relevance and accuracy of their feedback to peers: A case study. Assessing Writing 31, 1-11. doi.org/10.1016/j.asw.2016.07.002.

Crimmins, G.; Nash, G.; Oprescu, F.; Liebergreen, M.; Turley, J.; Bond, R. \& Dayton, J. (2014): A written, reflective and dialogic strategy for assessment feedback that can enhance student/teacher relationships, Assessment \& Evaluation in Higher Education, doi: 10.1080/02602938.2014.986644

Crisp, B. R. (2007). Is it worth the effort? How feedback influences students' subsequent submission of assessable work. Assessment and Evaluation in Higher Education, 32, 571-581. doi:10.1080/02602930601116912.

Ellery, K. (2008). Assessment for learning: A case study using feedback effectively in an essay-style test. Assessment and Evaluation in Higher Education, 33, 421-429. doi:10.1080/02602930701562981.

Ellis, R. (2005). Principles of instructed language learning. System, 33, 209-224

Ellis, R.; Sheen, Y.; Murakami, M. \& Takashima, H. (2008). The effects of focused and unfocused written corrective feedback in an English as a foreign language context. System 36, 353-371.

Ferris, D. (2014). Responding to student writing: Teachers' philosophies and practices. Assessing Writing, 19, 6-23.

Frear, D. \& Chiu, Yi-Hui. (2015). The effect of focused and unfocused indirect written corrective feedback on EFL learners' accuracy in new pieces of writing. System 53, 2434.

Hamlaoui, N. \& Fellahi, S. (2017). The role of teacher-student conferencing in improving grammatical accuracy in university EFL students' composition writing. Arab World English Journal, 8(1), 55-65. doi: https://dx.doi.org/10.24093/awej/vol8no1.5

Higgins, R.; Hartley, P. \& Skelton, A. (2002). The conscientious consumer: Reconsidering the role of assessment feedback in student learning, Studies in Higher Education, 27(1), 53-64, DOI: 10.1080/03075070120099368.

Hosseiny, M. (2014). The role of direct and indirect written corrective feedback in improving Iranian EFL students' writing skill. Procedia - Social and Behavioral Sciences, 98, 668 - 67.

Hyland, F. (2010). Future directions in feedback on second language writing: Overview and research agenda. International Journal of English Studies (IJES), 10(2), 171-182.

Mahfoodh, O. H. A. (2016). "I feel disappointed”: EFL university students' emotional responses towards teacher written feedback. Assessing Writing, 31, 1-20. 
McCarthy, J. (2015). Evaluating written, audio and video feedback in higher education summative assessment tasks. Issues in Educational Research, 25(2), 153-169.

Montgomery, J.L., \& Baker, W. (2007). Teacher-written feedback: Student perceptions, teacher self-assessment, and actual teacher performance. Journal of Second Language Writing, 16, 82-89.

Nakata, T. (2015). Effects of feedback timing on second language vocabulary learning: Does delaying feedback increase learning? Language Teaching Research, 19(4), 416434.

Nelson, M. M., \& Schunn, C. D. (2009). The nature of feedback: How different types of peer feedback affect writing performance. Instructional Science, 37, 375-401. doi:10.1007/s11251-008-9053-x.

Nemati, M.; Alavi, S. M.; Mohebbi, H. \& Masjedlou, A. P. (2017). Speaking out on behalf of the voiceless learners: Written corrective feedback for English language learners in Iran. Issues in Educational Research, 27:4, 822-841

Nicol, D.C \& Macfarlane-Dick, D. (2006). Formative assessment and self-regulated learning: a model and seven principles of good feedback practice. Studies in Higher Education, 31(2), 199-218 doi:10.1080/0307507060057209.

Peers, I. S. (2006) Statistical Analysis for Education and Psychology Researchers (Ebook). Taylor \& Francis e-Library.

Sendziuk, P. (2010). Sink or swim? Improving student learning through feedback and self-assessment. International Journal of Teaching and Learning in Higher Education, 22, 320-330

Shute, V. J. (2008). Focus on formative feedback. Review of Educational Research, 78, 153-189. doi:10.3102/0034654307313795.

Truscott, J. (1996) The case against grammar correction in L2 writing classes. Language Learning, 46(2), 327-369

Van Beuningen, C. G.; De Jong, N. H. \& Kuiken, F. (2008). The effect of direct and indirect corrective feedback on L2 learners' written accuracy. ITL International Journal of Applied Linguistics, 156, 279-296.

Van Beuningen, C. (2010). Corrective feedback in L2 writing: theoretical perspectives, empirical insights, and future directions. International Journal of English Studies, 10(2), 1-27

Wang, W. (2014). Students' perceptions of rubric-referenced peer feedback on EFL writing: A longitudinal inquiry. Assessing Writing, 19, 80-96.

Yeh, C-C. (2016). EFL college students' experiences and attitudes towards teacher student writing conferences." Journal of Response to Writing, 2(2), 37-65. 


\section{Appendix A (Cause-Effect Essay Writıng Prompt)}

\section{Writing Prompt}

a. Write a cause-and-effect essay in English on one of the following topics:

- The Effects of Using Social Media

- The Effects of Consuming Drugs

- The Causes of Traffic Accidents

b. Write a five-paragraph cause-and-effect-essay of approximately 300-450 words consisting of:

- One introductory paragraph

- Three supporting paragraphs

- One concluding paragraph

c. Be sure that every paragraph has a good topic sentence and clear supporting sentences.

d. Pay a careful attention at your use appropriate transitions and expressions for a cause-and-effect essay such as:

- Because of.., as a result of...

- So, for..

- Because, since,..

- ..cause.., .. result in...

- Etc.

e. Start your essay by making an outline and develop it into a good cause-effect essay.

f. You have to finish your outline at this end of this meeting and you may develop it into a good essay and submit it in the next meeting.

\section{Appendix B (Writing Scoring Rubric)}

\begin{tabular}{|c|c|c|c|c|}
\hline & 4 & 3 & 2 & 1 \\
\hline $\begin{array}{l}\text { Essay } \\
\text { Structure }\end{array}$ & $\begin{array}{l}\text { The introduction contains } \\
\text { clearly stated thesis } \\
\text { statement; the body fully } \\
\text { and competently examines } \\
\text { the topic by breaking it } \\
\text { down into causes and } \\
\text { effects; the conclusion } \\
\text { effectively ends the writing } \\
\text { without repetition, and } \\
\text { contains a clincher } \\
\text { statement; unity and } \\
\text { coherence is achieved } \\
\text { throughout; the overall } \\
\text { purpose is clear; causes and } \\
\text { effects are logical. }\end{array}$ & $\begin{array}{l}\text { The introduction } \\
\text { contains the thesis } \\
\text { statement; the body } \\
\text { examines the topic by } \\
\text { breaking it down into } \\
\text { causes and effects; } \\
\text { the conclusion brings } \\
\text { the writing to a close; } \\
\text { there is a generally } \\
\text { logical progression of } \\
\text { ideas and } \\
\text { information; overall } \\
\text { purpose is generally } \\
\text { clear; most causes } \\
\text { and effects are } \\
\text { logical. }\end{array}$ & $\begin{array}{l}\text { The introduction } \\
\text { contains the thesis } \\
\text { statement, but the } \\
\text { sentence may be } \\
\text { unclear, imprecise, or } \\
\text { inadequate; the body } \\
\text { explains at least one } \\
\text { cause and effect; a } \\
\text { conclusion is present } \\
\text { but may be weak or } \\
\text { repetitive, more logical } \\
\text { development is needed } \\
\text { throughout; the purpose } \\
\text { is not always obvious; } \\
\text { causes and effects are } \\
\text { not entirely clear or } \\
\text { logical. }\end{array}$ & $\begin{array}{l}\text { The introduction lacks a } \\
\text { thesis statement, or the } \\
\text { sentence is misleading or } \\
\text { unclear; the body does not } \\
\text { explain causes and effects; } \\
\text { the conclusion is missing, } \\
\text { contradictory, or repetitive; } \\
\text { the writing lacks unity and } \\
\text { coherence; the purpose is } \\
\text { not clear; causes and effects } \\
\text { are illogical or missing. }\end{array}$ \\
\hline $\begin{array}{l}\text { Language } \\
\text { Use }\end{array}$ & $\begin{array}{l}\text { There are few errors in } \\
\text { mechanics, grammar, or } \\
\text { spelling; word choice is } \\
\text { consistently careful and } \\
\text { often particularly precise } \\
\text { and powerful; transition } \\
\text { words and phrases are used } \\
\text { effectively. }\end{array}$ & $\begin{array}{l}\text { There are some errors } \\
\text { in mechanics, } \\
\text { grammar, or spelling; } \\
\text { most word choices } \\
\text { are precise; there is } \\
\text { some use of specific } \\
\text { cause-effect transition } \\
\text { words. }\end{array}$ & $\begin{array}{l}\text { There are many errors } \\
\text { in mechanics, grammar, } \\
\text { or spelling; several } \\
\text { word choices are } \\
\text { redundant, vague, or } \\
\text { imprecise; there is little } \\
\text { use of cause-effect } \\
\text { transition words. }\end{array}$ & $\begin{array}{l}\text { Expression is blocked by } \\
\text { numerous errors in } \\
\text { mechanics, grammar, or } \\
\text { spelling; word choice is } \\
\text { consistently confusing or } \\
\text { unclear; the writing lacks } \\
\text { cause-effect transition } \\
\text { words and phrases. }\end{array}$ \\
\hline
\end{tabular}




\begin{tabular}{|c|c|c|}
\hline \multicolumn{3}{|c|}{ Appendix C (Codes for Teacher Written Corrective Feedback) } \\
\hline Symbols & Meaning & Incorrect Sentence \\
\hline sv & $\begin{array}{l}\text { Subject-verb } \\
\text { agreement }\end{array}$ & $\begin{array}{l}\text { The student work hard. } \\
\text { There is tine employees }\end{array}$ \\
\hline S & No subject & A)ind it easier to study English. \\
\hline $\mathrm{pl}$ & Singular/plural & $\begin{array}{l}\text { The Internet has a lot gf informations. } \\
\text { You can-make new frfend easily. }\end{array}$ \\
\hline $\mathrm{sp}$ & spelling & The maneger is woman \\
\hline A & Article (a, an, the) & $\begin{array}{l}\text { Diners expec }(\wedge \text { glass of water when they first sit down at } \\
\text { their table. }\end{array}$ \\
\hline $\mathrm{p}$ & punctuation & I live in Bandung@ but I go to school in Jakarta. \\
\hline delete & $\begin{array}{l}\text { Unnecessary } \\
\text { word }\end{array}$ & My teacher she watches everyone all the time \\
\hline$\wedge$ & Add word/s & A camel is an anima $\wedge$ lyves in the desert. \\
\hline cap & capitalization & Some people love to drive (land)ruisers \\
\hline $\mathrm{vf}$ & Verb form & I am live) in the hostel \\
\hline $\mathrm{T}$ & Verb tense & Isee nhy friend yesterday. \\
\hline wf & Word form & The book is bored \\
\hline ww & Wrong word & My teache learns me many new things. \\
\hline wo & $\begin{array}{l}\text { Wrong word } \\
\text { order }\end{array}$ & We never(clas have on Fridays. \\
\hline Pron & $\begin{array}{l}\text { Pronoun } \\
\text { reference }\end{array}$ & My brother loves to swim. She goes swimming everyday. \\
\hline RO & Run-on sentence & $\begin{array}{l}\text { Lily failed the exam and she was upset and she went home } \\
\text { and her mother said she shouldn't cry }\end{array}$ \\
\hline $\mathrm{CS}$ & Comma splice & Mary was tired, she went to sleep. \\
\hline SF & $\begin{array}{l}\text { Fragment } \\
\text { (incomplete } \\
\text { sentence) }\end{array}$ & She was tired. Because she always went to bed at 3:00 AM \\
\hline ns/ & $\begin{array}{l}\text { Start a new } \\
\text { sentence here }\end{array}$ & $\begin{array}{l}\text { Sleep is importan, in addition, eating healthy food is } \\
\text { necessary. }\end{array}$ \\
\hline prep & preopsition & The cafeteria starts serving dinner(in $\phi .00 \mathrm{PM}$ \\
\hline conj & $\begin{array}{l}\text { Conjunction } \\
\text { missing or } \\
\text { incorrect }\end{array}$ & I like coffee@ndy don't like tea \\
\hline$?$ & I don't understand & vhat you want to say \\
\hline+ & Add details & \\
\hline Ev & Add evidence & \\
\hline TS? & No topic sentence & \\
\hline Th? & Confusing thesis st & tement \\
\hline // & Begin new paragra & \\
\hline$\rightarrow$ & Indent & \\
\hline
\end{tabular}

